\title{
Acute Metabolic Effects of Clenbuterol in Calves
}

\author{
By J. Luthman and S. O. Jacobsson
}

Department of Cattle and Sheep Diseases, Faculty of Veterinary Medicine, Swedish University of Agricultural Sciences, Uppsala, Sweden.

\begin{abstract}
Luthman, J., and S. O. Jacobsson: Acute metabolic effects of clenbuterol in calves. Acta vet. scand. 1993, 34, 169-174. - The acute metabolic effects of clenbuterol were studied in calves. Clenbuterol was given intravenously at a dose of $1 \mu \mathrm{g} / \mathrm{kg}$ body weight. Glucagon was used to increase insulin secretion. Pretreatment with clenbuterol did not change the glucagon-induced hyperglycæmia, but the serum levels of insulin were significantly higher. Clenbuterol showed a significant lipolytic effect. The post prandial increases in glucose and insulin were significantly higher in clenbuterol treated calves. The findings are in accordance with results from earlier studies where clenbuterol was given orally in much higher doses.
\end{abstract}

lipolysis; insulin.

\section{Introduction}

The B-agonists clenbuterol and cimaterol are known to change body composition by stimulation of muscle growth and reduction of fat accretion and are therefore often called repartitioners. By using these drugs in the feed it is possible to obtain clean meat from cattle, swine, lambs and poultry. The research in this field has been intense and a comprehensive review was published by Meersmann (1989). Besides the effect on body composition B-agonists also enhance growth and their use as feed additives has therefore been considered to be of significant economic importance. $\beta$ agonists are however not approved as growth promoters or repartitioners. In veterinary medicine clenbuterol is approved as a bronchodilator. It has also been suggested that Bagonists have a potential use in the treatment of obesity in man (Blum \& Flückiger 1988). The metabolic effects leading to the described changes are not completely understood. Muscle hypertrophy has been described in chronically treated animals by several authors e.g. Beermann et al. (1987), Hamby et al. (1986), and it was suggested from the results of Bohorov et al. (1987) that muscle hypertrophy probably is the result of decreased protein degradation.

B-agonists are known to have lipolytic properties (Luthman, 1972). There are however great differences between various species in the lipolytic response to $\beta$-agonists. It seems possible from the review of Meersmann (1989) that the reduction of adipose tissue in some species may be due to increased lipolysis in others to decreased lipogenesis.

The oral dose of clenbuterol used for repartitioning is $10-20 \mu \mathrm{g} / \mathrm{kg}$ body weight (Blum \& Flückiger 1988). The primary aim of the present investigation was to study the acute metabolic effects of the much lower parenteral dose used for broncho-dilatation (0.8-1 $\mu \mathrm{g} / \mathrm{kg})$.

\section{Material and methods}

Eleven calves of the Swedish Red and White Breed were used in the study. The calves were 4-6 weeks old and were held in individual 


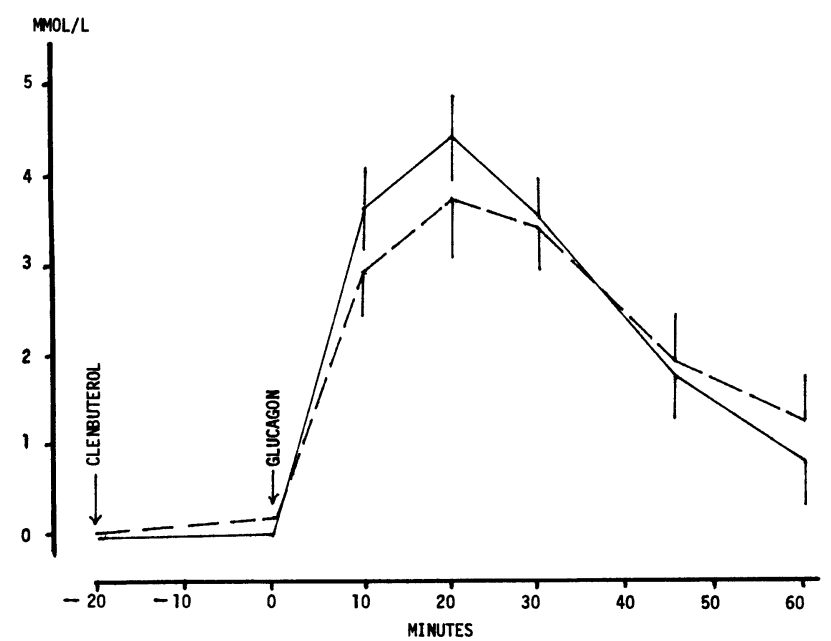

Figure 1. Influence of clenbuterol on the glucose response to glucagon in calves $(\mathrm{n}=5)$. Glucagon, $4 \mu \mathrm{g} / \mathrm{kg}$ i.v. -. Clenbuterol $(1 \mu \mathrm{g} / \mathrm{kg})+$ glucagon ----. Clenbuterol was given $20 \mathrm{~min}$ before glucagon.

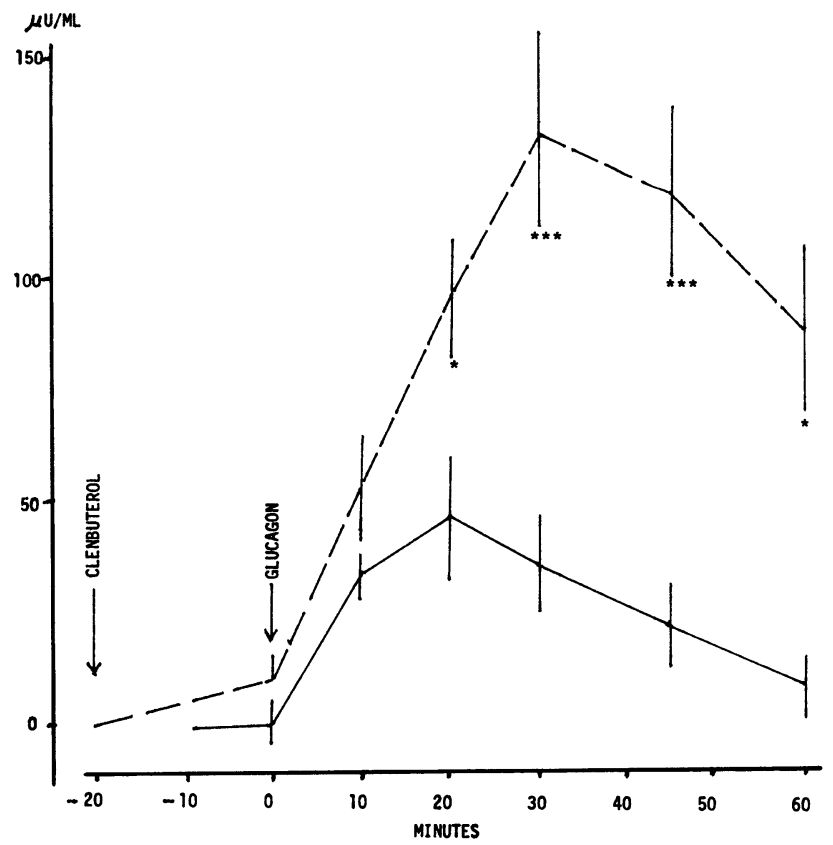

Figure 2. Influence of clenbuterol on the insulin response to glucagon in calves $(\mathrm{n}=5)$. Glucagon, $4 \mu \mathrm{g} / \mathrm{kg}$ i.v. - Clenbuterol $(1 \mu \mathrm{g} / \mathrm{kg}+$ glucagon ----. Clenbuterol was given $20 \mathrm{~min}$ before glucagon. $* * * \mathrm{p}<0.001$. $* 0.01<\mathrm{p}<0.05$. 


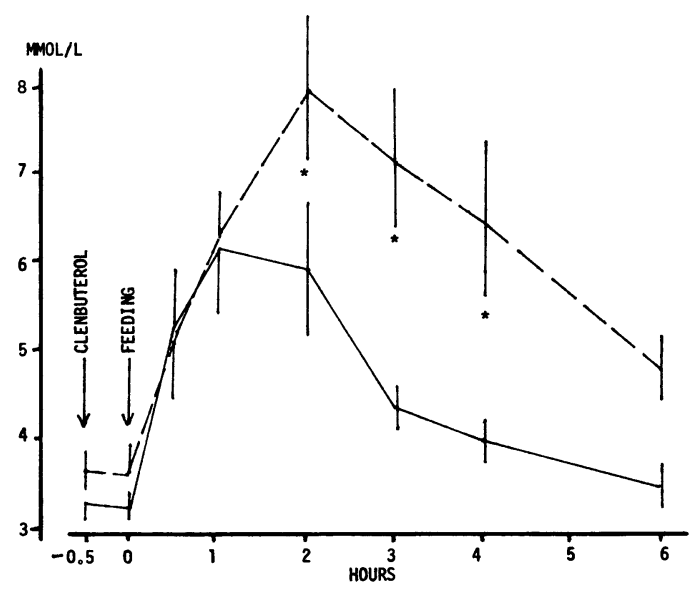

Figure 3. Post prandial changes in blood glucose, before — and after ---- clenbuterol treatment. $n=6$. $* 0.01<\mathrm{p}<0.05$.

pens. Milk replacer (2.5 l) was fed twice daily and the animals had free access to hay. Glucagon stimulates the release of insulin, and the influence of clenbuterol on glucagoninduced insulin release was studied in the first experiment. Five non-fasted calves were used. The animals were given an intravenous injection of glucagon, $4 \mu \mathrm{g} / \mathrm{kg}$ body weight, and blood was sampled for analysis of glucose and insulin. The experiment was repeated after 3 days but at that occasion $1 \mu \mathrm{g} / \mathrm{kg}$ of clenbuterol was injected intravenously 20 min.before glucagon.

Glucagon was obtained from Novo Nordisk Pharma AB,202 15 Malmö,Sweden and clenbuterol was a gift from Boehringer Ingelheim Agrovet,217 48 Malmö,Sweden.

The influence of clenbuterol on the post prandial changes in insulin, glucose and non-esterified fatty acids (NEFA) were studied in the second experiment. Six calves were used in an experiment of cross-over design. Three of the calves were given $1 \mu \mathrm{g} / \mathrm{kg}$ of clenbuterol intravenously $30 \mathrm{~min}$. before the first milk-feeding of the day, the others served as controls. The experiment was repeated after a week in a way so that all calves were treated with clenbuterol.

Pharmacia Insulin RIA 100 (Pharmacia Diagnostics AB, S-75182 Uppsala,Sweden) was used for insulin analysis.

Non-esterified fatty acids (NEFA) and glucose was analysed enzymatically (Wako NEFA C,B-B Diagnostics,S-10462 Stockholm, Sweden and Uni-kit 111, Roche Produkter AB,S-127 25 Skärholmen, Sweden). Student's t-test was used for statistical calculations. All values given in text and figures are means \pm standard error of the mean.

\section{Results}

The influence of clenbuterol on glucagon-induced hyperglycemia and hyperinsulinemia is shown in Figs. 1 and 2. The animals were nonfasted, the figures therefore shows the changes from the base-line levels. The preinjection level of glucose was $4.00 \pm 1.13 \mathrm{mmol} / \mathrm{l}$ in the controls and $4.6 \pm 1.24$ before clenbuterol treatment. Corresponding values for insulin were $6.09 \pm 0.44 \mu \mathrm{U} / 1$ and 9.58 $\pm 3.82 \mu \mathrm{U} / \mathrm{l}$. As seen from Fig 1 clenbuterol had no influence on the glucagon-induced hyperglycemia, 


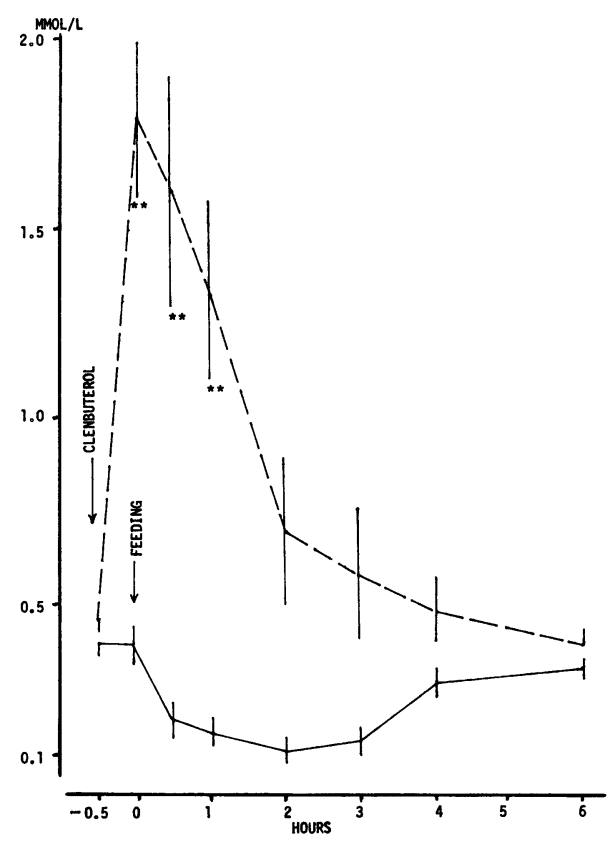

Figure 4. Post prandial changes in NEFA, before - and after ---- clenbuterol treatment. $n=6$.

$* * 0.001<\mathrm{p}<0.01$.

while the insulin levels were significantly higher after clenbuterol treatment.

The effects of clenbuterol on the post prandial changes in glucose, NEFA and insulin are shown in Figs. 3-5. All animals consumed the milk replacer within 3-5 min.

It is obvious from Fig. 3 that clenbuterol did not influence the blood glucose level, since the means did not differ between $-30 \mathrm{~min}$. and zero (immediately before feeding). The lipolytic effect of clenbuterol is demonstrated in Fig. 4, at $-30 \mathrm{~min}$. NEFA was $0.42 \pm 0.10 \mathrm{mmol} / \mathrm{l}$ and at zero the mean had increased to $1.81 \pm 0.20 \mathrm{mmol} / 1$. Insulin did not change during the same period (Fig. 5).

The expected changes after feeding occurred in the controls, blood glucose and insulin increased while NEFA decreased. Clenbuterol increased the glucose and insulin response to feeding significantly and caused a remarkable increase in NEFA.

No serious adverse effects were observed after injection of clenbuterol, but single calves showed transient muscle tremor.

\section{Discussion}

Glucagon stimulates insulin secretion by mechanisms which are supposed to act directly on the B-cells and indirectly by increasing the blood glucose level. Glucagon injections can therefore be used to study insulin release. The method was successfully used in man by Ahrén et al. (1987) and in dairy cows by Holtenius \& Tråvén (1990). As shown in Fig. 2 the method is useful also in calves.

Fig. 1 shows that glucagon-induced hyperglycemia was not influenced by clenbuterol, while the insulin levels were significantly incresed. 


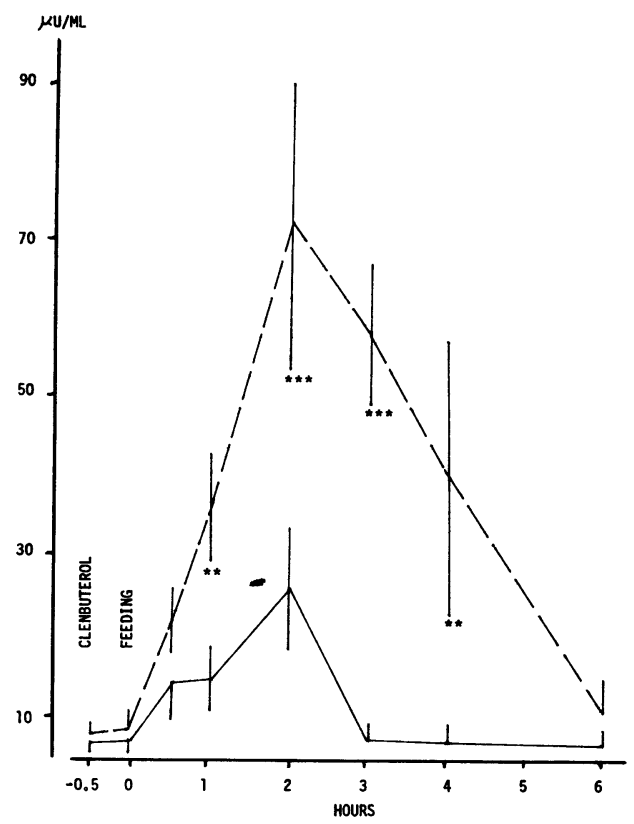

Figure 5. Post prandial changes in serum insulin, before — and after ---- clenbuterol treatment. $\mathrm{n}=6$. $* * * \mathrm{p}<0.001, \quad * * 0.001<\mathrm{p}<0.01$.

The levels of glucose and insulin were signifiantly higher after clenbuterol treatment. It is obvious that clenbuterol is a potent lipolytic agent in calves, since NEFA increased remarkably after feeding. The control group on the other hand showed the expected decline. Earlier studies with norepinephrine in ruminants (Luthman 1972) showed that this B-agonist has both glycogenolytic and lipolytic properties. It seems as clenbuterol has no glycogenolytic properties in calves as blood glucose did not increase within the $30 \mathrm{~min}$. from injection to feeding (Fig. 3).

The results are very similar to what has been reported earlier after oral doses of 10-25 $\mu \mathrm{g} / \mathrm{kg}$ body weight given in milk replacer (Blum \& Flückiger 1988).They concluded that the effects on glucose, NEFA and insulin were mediated by $\beta$-adrenoceptors as all effects could be fully inhibited by the $\beta$-antagonist
propranolol.It was also suggested that clenbuterol induces insulin resistance within hours, since the calves showed decreased glucose clearence rate and an excessive insulin response when glucose tolerance tests were performed 6 hours after clenbuterol administration. The results were confirmed in a later study (Zimmerli \& Blum1990) where it also was demonstrated that clenbuterol treated calves showed no blood glucose response to insulin. The most interesting results were however that the studied metabolic effects of clenbuterol disappeared after prolonged treatment. The post prandial changes in blood glucose, NEFA and insulin were normalized after 14 days of treatment. The results agree with other studies where it was shown that basal lipolysis was unaffected or depressed after long-term treatment with B-agonists (Meersmann et al. 1987, Miller et al. 1988). 
It seems probable that the long-term effects of ß-agonists are more important for repartition of nutrients than the acute effects. Beerman et al. (1987) demonstrated that lambs fed B-agonists for several weeks showed lower blood levels of somatotropin, insulin and thyroxine than the controls. These endocrine changes may partly explain the long-term effects of $\beta$ agonists.

Clenbuterol is approved in Sweden for the treatment of bronchospasm in horses. The recommended dose is $0.8 \mu \mathrm{g} / \mathrm{kg}$. The results from the present study show that parenteral doses at this level induce the same acute metabolic changes in calves as the higher oral doses (up to $20 \mu \mathrm{g} / \mathrm{kg} /$ day) which are used for repartition and growth enhancement.

\section{References}

Ahrén B, Nobin A, Scherstén B: Insulin and C-peptide secretory response to glucagon in man: Studies on the dose-response relationships. Acta med.scand. 1987, 221, 185-190.

Beermann DH, Butler RW, Hogue DE, Fishell VK, Dalrymple RH, Ricks CA, Scanes CG: Cimaterol-induced muscle hypertrophy and altered endocrine status in lambs. J.Anim.Sci. 1987, 65, 1514-1524.

Blum J. Flückiger N: Early metabolic effects of perorally administrated B-adrenoceptor agonists in calves. Eur.J.Pharmacol. 1988, 151, 177-187.

Bohorov O, Buttery PJ, Correia JHR, Soar JB: The effect of the B-2-adrenergic agonist clenbuterol or implantation with oestradiol plus trenbolon acetate in protein metabolism in wether lambs. Brit.J.Nutr. 1987, 57, 99-107.

Hamby PL, Stouffer JR, Smith SB: Muscle metabolism and real-time ultrasound measurement of muscles and subcutaneous adipose tissue growth in lambs fed diets containing a beta-agonist. J.Anim.Sci. 1986, 63, 1410-1417.

Holtenius P, Tråvén, M: Impaired glucose tolerance and heterogeneity of insulin responses in cows with abomasal displacement. J.vet.Med. A, 1990, 37, 445-450.

Luthman J: Lipid mobilization in ruminants. Thesis, Stockholm 1972.

Meersmann HJ: Potential mechanisms for repartitioning of growth by $\beta$-adrenergic agonists. In: Campion DR, Hausman GJ, Martin RJ. (eds.) Animal Growth Regulation. Plenum Press, New York and London, 1989.

Meersmann HJ, Hu CY, Pond WG, Rule DC, Novakofski JE, Smith SB: Growh and adipose tissue metabolism in young pigs fed cimaterol with adequate or low dietary protein. J.Anim.Sci. 1987, 64, 1384-1394.

Miller JF, Garcia DK, Coleman ME, Ekeren PA, Lunt DK, Wagner KA, Procknor M, Welch TH, Smith SB: Adipose tissue, longissimus muscle and anterior pituitary growth and function in clenbuterol fed heifers. J.Anim.Sci. 1988, 66, 1220.

Zimmerli UV, Blum J: Acute and longterm metabolic endocrine, respiratory, cardiac and skeletal muscle activity changes in response to perorally administered $\mathrm{B}$-adrenoceptor agonists in calves. J.Anim.Physiol.Anim.Nutr. 1990, 63, 157-172.

\section{Sammanfattning \\ Akuta metaboliska effekter av clenbuterol hos kalv.}

De akuta metaboliska effekterna av ß-agonisten clenbuterol studerades hos kalv. Clenbuterol gavs intravenöst i dosen $1 \mu \mathrm{g} / \mathrm{kg}$.

Glukagon användes för att öka insulinsekretionen. Clenbuterol hade ingen effekt på glukagon-inducerad hyperglukemi, däremot var insulinnivåerna signifikant högre hos djur som förbehandlats med clenbuterol. Den lipolytiska effekten av clenbuterol var mycket påtaglig. Djur som behandlats med clenbuterol visade signifikant högre serumkoncentrationer av glukos, fria fettsyror och insulin efter utfodring. Resultaten är i överensstämmelse med tidigare studier där clenbuterol givits oralt i mycket högre doser.

(Received December 23, 1992; accepted January 11, 1993).

Reprints may be requested from: J. Luthman, Department of Cattle and Sheep Diseases, Swedish University of Agricultural Sciences,S-750 07 Uppsala, Sweden. 